\title{
PENINGKATAN PENGUASAAN MUFRADAT MAHASISWA MELALUI MEDIA BERBASIS TEKS CERITA
}

\author{
Khaerunnisa Nuur \\ Email: hjnisa82@gmail.com \\ Fakultas Adab dan Humaniora UIN Alauddin Makassar
}

\begin{abstract}
This article discussed about the way of increasing the students' mastery of mufradat through the story of text media. The mastery process of mufradat is still less effective among them because they cannot use learning media well that caused the students are not interested in learning Arabic. Media has important roles in learning process. Media text stories are the story related to learning materials that serve to convey messages from lecturers to students. The way of using media as medium to increase mufradat mastery to improve the ability of Arabic students' especially in mastery of mufradat and they can also improve their capability in mastering the appropriate method in learning process and selecting learning media effectively and efficiently.
\end{abstract}

Keywords: Mufradat, story of text media, mastery, learning process, Arabic

\begin{abstract}
Abstrak
Artikel ini membahas bagaimana peningkatan penguasaan mufradat mahasiswa melalui media teks cerita. Di kalangan mahasiswa, proses penguasaan mufradat masih kurang efektif karena belum dapat memanfaatkan media pembelajaran secara baik sehingga minat belajar mahasiswa dalam bahasa Arab menjadi berkurang. Keberhasilan suatu proses pembelajaran tidak terlepas dari peran media di dalamnya. Media teks cerita adalah suatu cerita yang berkaitan dengan materi pembelajaran yang berfungsi untuk menyampaikan pesan dari dosen kepada mahasiswa. Langkah- langkah penggunaan media berbasis teks cerita untuk meningkatkan penguasaaan mufradat yang bertujuan untuk meningkatkan kemampuan mahasiswa dalam bahasa Arab khususnya dalam penguasaan mufradat di samping itu juga dapat meningkatkan keterampilan dalam penggunaan metode yang tepat dalam proses pembelajaran dan pemilihan media pembelajaran yang lebih efektif dan efisien.
\end{abstract}

Kata kunci: Mufradat, Media Teks Cerita, Penguasaan. Proses pembelajaran, Bahasa Arab. 


\section{A. Pendahuluan}

Manusia merupakan makhluk sosial yang perlu berinteraksi dengan manusia lainnya, kegiatan berinteraksi tersebut membutuhkan alat, sarana atau media yakni bahasa. Bahasa adalah sebagai alat komunikasi yang yang paling efektif untuk menyampaikan gagasan, pikiran, maksud dan tujuan kepada orang lain. Bahasa tidak pernah lepas dari setiap kegiatan manusia sepanjang keberadaan manusia itu sebagai makhluk yang berbudaya dan bermasyarakat karena ia berfungsi sebagai sarana komunikasi, sarana integrasi dan sarana adaptasi. Di sisi lain, bahasa juga memiliki keistimewaan yang populer di kalangan manusia dan bangsa manapun untuk mengekspresikan kebutuhan mereka.

Manusia mampu mengungkapkan berbagai macam peristiwa dalam kehidupan bermasyarakat dengan menggunakan kosakata yang tersusun dalam kalimat. Kosakata merupakan salah satu unsur yang penting dalam semua bahasa, termasuk di antaranya bahasa Arab. Dalam proses pembelajaran bahasa asing, aspek penguasaan terhadap kosakata merupakan aspek yang sangat penting untuk dikuasai.

Bahasa Arab yang dipakai dalam masyarakat terus berkembang menurut perkembangan zaman, terutama pada zaman kemajuan ilmu pengetahuan dan teknologi modern sekarang. Dapat dikatakan bahwa hampir seluruh bidang ilmu pengetahuan seperti ilmu filsafat, ilmu kedokteran, ilmu pasti, kimia dan sastra yang dikenal orang pada masa itu sudah diterjemahkan ke dalam bahasa Arab. ${ }^{1}$ Di samping timbulnya kata-kata baru, kata-kata lama juga mengalami perubahan dalam arti. Bahkan tidak berlebih kalau dikatakan bahwa untuk memahami al-Qur'an dan ajaran-ajaran Islam yang sebenarnya, pengetahuan bahasa Arab merupakan syarat mutlak, ${ }^{2}$ khususnya penguasaan mufradat al-Qur'an. ${ }^{3}$

Bahasa Arab adalah salah satu bahasa internasional yang selalu berkembang dan sampai kepada saat ini melalui proses transformasi sehingga bermunculan model-model dan teknik pembelajaran interaktif-alternatif yang dapat menambah minat dalam mempelajari bahasa Arab secara simultan dan berkelanjutan. Karena begitu pentingnya aspek penguasaan kosakata dalam bahasa Arab, maka dibutuhkan improvisasi dalam segi metodologi ${ }^{4}$ dan teknik pembelajarannya.

${ }^{1}$ Latifah Salim, "Peranan Bahasa Arab terhadap Ilmu Pengetahuan”, Jurnal Adabiyah Vol. 15 Nomor 2/2015, h. 172. Diakses pada http://journal.uin-alauddin.ac.id/index.php/adabiyah/article/view/701/pdf_50 311.

${ }^{2}$ Harun Nasution, Islam Rasional: Gagasan dan Pemikiran (Cet. I; Bandung: Mizan, 1995), h.

${ }^{3}$ Pengetahuan dan penguasaan mufradat menjadi bagain penting dalam memahami isi kandungan al-Qur'an sehingga metode tahlili sebagai salah satu metode penafsiran al-Qur'an menekankan pada penguasaan mufradat ayat-ayat al-Qur'an. Sebagai contoh kitab tafsir yang menggunakan metode ini adalah al-Bahr al-Muhîth karya Abu Hayyân al-Andalusî. Lihat H. M. Rusydi Khalid, "Al-Bahru al-Muhīt", Jurnal Adabiyah Vol. 15 Nomor 2/2015, h. 183. Diakses pada http://journal.uin-alauddin.ac.id/index.php/adabiyah/article/view/702

${ }^{4}$ Metodologi merupakan caara atau metode yang digunakan oleh manusia untuk mencapai pengetahuan tentang kebenaran dalam aspek prsial maupun menyeluruh. Metodologi memegang peranan besar dalam mengembangkan pendidikan. Sebuah metode pendidikan memiliki pengaruh pada metode belajar dan perilaku peserta didik. Dalam proses kelahirannya, metodologi dipengaruhi oleh kondisi lingkungan, budaya dan filosofis. Lebih lanjut lihat Ulil Amri Syafri, Pendidikan Karakter Berbasis Al-Qur'an (Cet.II; Jakarta: RajaGrafindo Persada, 2014), h. 50-51. 
Metodologi dalam pembelajaran bahasa memiliki peranan penting, sehingga muncul tagline bahwa al-tariqatu ahammu min al-mäddah yang berarti metode pengajaran lebih penting dari pada materi pelajaran. Dalam perencanaan kurikulum, banyak ahli menjadikan metodologi sebagai bagian dari prosedur perencanaan seperti Tarigan mengemukakan bahwa beberapa prosedur perencanaan kurikulum dalam pengembangan kurikulum bahasa terdiri dari: Analisis kebutuhan, penetapan tujuan, rancang bangun silabus, metodologi, pengujian dan penilaian. ${ }^{5}$ Haniah menyimpulkan bahwa prosedur perencanaan yang dikemukakan oleh Ibrahim, Richard, Dakir, Hamalik dan Tarigan terdapat unsur-unsur yang sama diantaranya adalah analisis kebutuhan, analisis situasi, penetapan tujuan yang selanjutnya menentukan isi, sarana, metode dan terakhir adalah evaluasi. ${ }^{6}$

Penerapan suatu metode ke dalam setiap situasi pembelajaran haruslah mempertimbangkan serta memperhatikan berbagai kemungkinan yang dapat mempertinggi mutu dan efektivitas suatu metode tertentu. Jika hal ini diabaikan maka bukan saja proses pengajaran yang terhambat akan tetapi juga bisa mengakibatkan tidak tercapainya tujuan dalam pemilihan metode tersebut meliputi tujuan yang hendak dicapai, kemampuan guru, anak didik, situasi dan kondisi pengajaran di mana berlangsung, fasilitas yng tersedia, waktu yang tersedia, kebaikan dan kekurangan suatu metode. ${ }^{7}$

\section{B. Pembahasan}

\section{Penguasaan mufradat dalam bahasa Arab}

Kosakata yang berarti perbendaharaan kata adalah himpunan kata atau khazanah kata yang diketahui oleh seseorang atau etnis lain, atau merupakan bagian dari suatu bahasa tertentu. Penguasaan mufradat dalam bahasa Arab yang dimaksud dalam tulisan ini adalah kemampuan seseorang dalam menggunakan mufradat yang dimiliki untuk berkomunikasi dan mengungkapkan ide ataupun gagasan dengan lingkungannya baik secara lisan maupun tulisan yang ditandai dengan berkembangnya keterampilan atau kemampuan dasar berbahasa yaitu menyimak, menulis, berbicara dan membaca menggunakan bahasa Arab. ${ }^{8}$

Tidak dapat dipungkiri bahwasanya keterampilan berbahasa membutuhkan penguasaan kosakata yang memadai. Penguasaan kosakata yang memadai itu akan dapat menentukan kualitas seseorang dalam berbahasa, baik secara lisan maupun tulisan. Bahkan ada yang mengatakan bahwa tingkat penguasaan keterampilan

${ }^{5}$ Henry Guntur Tarigan dalam Haniah, "Manajemen Perencanaan Kurikulum Bahasa Arab", Jurnal PELITA, Volume 4, Nomor 2, Juli-Desember 2012, h. 295. Diakses pada http://repositori.uinalauddin.ac.id/1973/1/Jurnal\%20Haniah_Pelita_2012.pdf

${ }^{6}$ Haniah, Jurnal PELITA, Volume 4, Nomor 2, Juli-Desember 2012, h. 295.

${ }^{7}$ Tayar Yusuf dan Syaiful Anwar, Metodologi Pengajaran Agama dan Bahasa Arab (Cet. II; Jakarta: RajaGrafindo Persada, 1997), h. 6-10.

${ }^{8}$ Keterampilan tersebut ada empat, yaitu keterampilan menyimak (maharah alistimal listening skill), berbicara (maharah al-kalam/speaking skill), membaca (maharah al-qiraah / reading skill) dan menulis (maharah al-kitabah/writing skill). Keempat keterampilan ini memiliki hubungan hierarkis yang tidak bisa dipisahkan satu sama lainnya. Lihat Zulhannan, Teknik Pembelajaran Bahasa Arab Interaktif(Cet. II; Jakarta; PT RajaGrafindo Persada, 2015), h. 76. 
berbahasa seseorang diukur lewat kemampuannya menguasai kosakata, baik dari kamus, buku bacaan, maupun hasil menyimak ${ }^{9}$.

Pengembangan teknik pembelajaran mufradat dapat dilakukan sebagai berikut : ${ }^{10}$

1. Al-kalimat al-Mutaqathi'ah, teknik ini digunakan untuk lebih memantapkan mahasiswa dalam memahami teks cerita yang telah dibaca. Adapun langkahlangkah yang yang digunakan dalam teknik Al-kalimat al-Mutaqathi'ah ini, yaitu :

a) Dosen menentukan kata kunci yang berkaitan dengan teks cerita yang telah dipelajari. Kemudian membuat pernyataan yang jaawabannya mengarah kepada mufradat tersebut.

b) Dosen membuat kisi-kisi yang dapat diisi dengan kaata-kata yang telah dipilih.

c) Mahasiswa diminta untuk mengisi secara perlahan-lahan atau kelompok dengan batas waktu yang telah ditentukan.

d) Dosen memberi batasan waktu dalam mengerjakaannya.

e) Pemberian reward bagi mahasiswa yang telah mengerjakan secara baik dan benar.

2. Al-Kalimah al-Musalsalah, teknik ini dapat digunakan untuk mendapatkan perbendaharaan mufradat yang bervariasi. Adapun langkah-langkah yang digunakan dalam teknik Al-Kalimah al-Musalsalah ini, yaitu:

a) Dosen mengatur tempat duduk (kursi) mahasiswa dalam formasi lingkaran dan mengambil salah satu kursi dalam lingkaran tersebut.

b) Dosen menyebutkan salah satu kata misalnya kata fataha, kemudian mahasiswa disebelahnya diharuskan untuk meneruskan kata selanjutnya setelah kata fataha tersebut, misalnya kata Mahmud sehingga menjadi rangkaian fataha Mahmud.

c) Mahasiswa berikutnya pun diharuskan untuk meneruskan kata selanjutnya setelah kata Mahmud tersebut, misalnya kata al-Nafidzata, sehingga menjadi rangkaian fataha Mahmud al-Nafidzata dan demikian hal tersebut dilakukan secara berkelanjutan dan diusahakan rangkaian kalimatnya tidak terputus, akan tetapi selalu berkait atau beruntun.

3. Ta'bir al-Kalimah al-Faba'iyyah, teknik ini digunakan untuk memproduksi kata dengan cepat dalam waktu yang relatif singkat. Adapun langkah-langkah yang yang digunakan dalam teknik Ta'bir al-Kalimah al-Faba'iyyah ini, yaitu:

a). Dosen mengatur tempat duduk ( kursi ) mahasiswa dalam formasi lingkaran dan mengambil salah satu kursi dalam lingkaran tersebut.

b) Dosen menyebutkan sebuah kata dengan menentukan kategorinya yaitu isim atau fi'il. Misalnya kata 'Inab (anggur) yang termasuk dalam kategori isim sehingga dengan demikian kata yang akan disebutkan oleh mahasiswa berikutnya haruslah dalam kategori isim pula. Akan tetapi mahasiswa berikutnya harus menyebutkan kata yang awal hurufnya

${ }^{9}$ Acep Hermawan, Metodologi Pembelajaran Bahasa Arab (Cet. IV; Bandung: PT Remaja Rosdakarya, 2014), h. 193.

${ }^{10}$ Zulhannan, Teknik Pembelajaran Bahasa Arab Interaktif, h.194-197 
merupakan huruf akhir dari kata sebelumnya, misalnya kata 'Inab huruf akhirnya adalah ب maka dengan demikian mahasiswa harus menyebutkan kata kategori isim yang berawalan ب misalnya kata ba'udah (nyamuk), demikian seterusnya berlanjut sampai selesai.

c) Strategi ini bisa menggunakan pola lain, yaitu dosen menyebutkan satu huruf misalnya huruf $>$ dan selanjutnya mahasiswa diharuskan untuk melanjutkan menyebutkan kata yang dimulai dari huruf $م$ tersebut, seperti kata mauzun, manja, miah, dan seterusnya.

4. Al-Ard al-Shuwar, teknik ini digunakan untuk berekspresi dengan berbagai perbendaharaan kata yang terkait dengan objek maupun gambar yang ada dalam teks cerita. Adapun langkah-langkah yang yang digunakan dalam teknik Al-Ard al-Shuwar ini, yaitu :

a) Dosen membagi mahasiswa menjadi dua kelompok.

b) Dosen menunjuk objek tertentu yang ada dalam teks.

c) Masing-masing kelompok mahasiswa diminta untuk mengidentifikasi objek tersebut dan menyebutkan sebanyak-banyaknya mufradat yang berkait an dengan objek tersebut.

d) Kelompok yang paling banyak menyebutkan mufradat yang berkaitan dengan objek tersebut diberikan reward.

5. Al-kalimah al-Gharibah Takhruj, teknik ini digunakan dalam menelaah kata. Adapun langkah-langkah yang yang digunakan dalam teknik Al-kalimah alGharibah Takhruj ini, yaitu :

a) Dosen menyediakan 10 sampai 15 mufradat yang bervariasi, di mana tiap kumpulan kata tersebut terdapat satu kata yang tidak sejenis, contoh : dan lain-lain.

b) Minta mahasiswa mencatat mufradat tersebut dan mengeluarkan mufradat yang tidak sejenis

c) Minta salah seorang atau dua mahasiswa untuk menunjukkan kalimat yang asli itu, sambil menjelaskan sebabnya.

d) Tanya mahasiswa selain keduanya untuk meng-cross-check jawaban beserta argumentasinya. ( Dosen hendaknya tidak menunjukkan jawaban yang benar, sebelum tuntas solusi yang ditawarkan seluruh mahasiswa yang ada dalam kelas ).

e) Bila waktu yang ditentukan tidak mencukupi dan belum ada jawaban yang tepat, baarulah dosen memberikn klarifikasi.

6. Al-Kalimah al-Mujawizah, teknik ini digunakan untuk mengetahui katakaataa majemuk dalam bahasa Arab dengan cepat dan tepat. Adapun langkahlangkah yang yang digunakan dalam teknik Al-Kalimah al-Mujawizah, ini, yaitu :

a) Dosen mempersiapkan mufradat yang mempunyai sinonim atau antonim dan menuliskannya pada potongan kertas yang digulung.

b) Masing-masing mahasiswa mendapatkan potongan kertas yang sudah digulung tersebut.

c) Dosen membagi mahasiswa menjadi dua kelompok,

d) Dosen meminta kelompok 1 untuk membaca isi kertas tersebut dengan suara nyaring, sementara kelompok 2 diminta untuk mencari pasangan 
mufradat yang telah dibacakan tersebut (baik yang sinonim maupun yang antonim).

\section{Penggunaan Media Teks Cerita}

Kata media berasal dari bahasa Latin medius yang secara haarfiah berarti tengah, perantara, atau pengantar. Dalam bahasa Arab, media adalah perantara (وسائل) atau pengantar pesan dari pengirim kepada penerima pesan. ${ }^{11}$ Media menyampaikan suatu informasi dari sebuah sumber yang berupa apa saja yang dapat memberikan atau menjadi sumber informasi. Media juga berfungsi untuk tujuan instruksi di mana informasi yang terdapat dalam media itu harus melibatkan peserta didik baik dalam benak atau mental maupun dalaam bentuk aktifitas yang nyata sehingga pembelajaran dapat terjadi. Meteri harus dirancang secara lebih sistematis dan psikologis dilihat dari segi prinsip-prinsip belajar agar dapat menyiapkan instruksi yang efektif. Di samping menyenangkan, media pembelajaran harus dapat memberikan pengalaman yang menyenangkan dan memenuhi kebutuhan mahasiswa $^{12}$.

Penggunaan media dalam pengajaran bahasa bertitik tolak dari teori yang mengatakan bahwa totalitas presentase banyaknya ilmu pengetahuan, keterampilan, dan sikap yang dimiliki oleh seseorang terbanyak dan tertinggi melalui indra lihat dan pengalaman langsung melakukan sendiri, sedangkan selebihnya melalui indra dengar dan indra lainnya. ${ }^{13}$ Media teks cerita merupakan salah satu media pembelajaran yang salah satu kegunaannya yakni untuk meningkatkan penguasaan mufradat yang didahului oleh latihan pengucapan yang benar dan pemahaman.

Beberapa strategi pembelajaran aktif berikut dapat dipergunakan untuk merangsang penguasaan mufradat mahasiswa melalui teks cerita:

\section{a. Strategi 1}

Tujuan dari strategi ini biasanya digunakan untuk melatih kemampuan mahasiswa mengelompokkan mufradat dari teks cerita ke dalam bentuk tabel. Misalnya mahasiswa dapat menemukan sejumlah kata benda (isim) dan kata kerja (fi'il) yang ada dalam bacaan. Untuk kebutuhan tersebut, maka tabel yang dibuat terdiri atas dua kolom yang berisi deretan isim dan fi'il adapun jumlah barisnya ditentukan batasannya oleh dosen (jumlah maksimal yang dapat ditemukan atau jumlah minimal yang harus ditemukan dari bacaan tersebut). Langkah-langkahnya:

1. Dosen memilih bacaan sesuai dengan topik pembahasan yang telah ditentukan.

2. Dosen menyiapkan format tabel yang akan digunakan para mahasiswa.

3. Dosen membagikan bacaan tersebut pada masing-masing mahasiswa, kemudian tugaskan mereka untuk membacanya dengan seksama.

4. Dosen meminta para mahasiswa unt uk mengisi tabel yang telah dipersiapkan.

5. Dosen meminta para mahasiswa untuk bergabung dua-dua (dengan teman di sebelahnya) kemudian mendiskusikan hasil kerja mereka masing-masing.

6. Dosen meminta masing-masing mahasiswa untuk menyampaikan (presentasi) hasil pekerjaan mereka setelah didiskusikan.

\footnotetext{
${ }^{11}$ Azhar Arsyad, Media Pembelajaran (Cet.V; Jakarta: RajaGrafindo Persada, 2004), h. 3.

${ }^{12}$ Azhar Arsyad, Media Pembelajaran, h. 21.

${ }^{13}$ Acep Hermawan, Metodologi Pembelajaran Bahasa Arab, h.224-225.
} 
7. Dosen memberikan klarifikasi terhadap hasil kerja mahasiswa tersebut agar tidak terjadi kesalahan.

\section{b. Strategi 2}

Strategi ini digunakan untuk mengajarkan kata-kata atau kalimat dengan pasangannya. Misalnya kata dengan artinya, atau soal dengan jawabannya, dan sebagainya. Hal ini diterapkan untuk melakukan evaluasi terhadap pemahaman mahasiswa terhadap isi bacaan dengan membuat kartu-kartu soal dan jawabannya. Langkah-langkahnya adalah:

1. Dosen menyiapkan kartu berpasangan (soal dan jawabnya) lalu diacak.

2. Dosen membagikan kartu tersebut kepada semua mahasiswa dan mintalah mereka memahami artinya.

3. Dosen meminta semua mahasiswa untuk mencari pasangannya masing-masing dengan tanpa bersuara.

4. Setelah menemukan pasangannya, dosen meminta mahasiswa berkelompok dengan pasangannya masing-masing.

5. Mintalah masing-masing kelompok untuk menyampaikan (mempresentasikan) hasilnya di depan kelas

6. Berikan kesempatan kepada kelompok lain untuk memberikan komentar atau pertanyaan.

7. Dosen memberikan klarifikasi terhadap hasil kerja kelompok tersebut.

\section{c. Strategi 3}

Strategi ini dapat diterapkan untuk melatih mahasiswa dalam menyusun sebuah naskah yang sistematis. Mahasiswa juga dilatih untuk memahami isi bacaan tidak hanya secara global, tetapi sampai pada bagian-bagian yang paling kecil sampai akhirnya dapat menyusun kembali bacaan tersebut secara runtut. Secara teknis, strategi ini dapat dipraktikkan untuk mengurutkan kalimat-kalimat dalam satu alinea, atau mengurutkan beberapa alinea dalam satu bacaan lengkap ${ }^{14}$

\section{A. Sebelum Masuk Kelas}

1) Dosen memilih suatu topik cerita yang memungkinkan dapat dibagi rata mufradat ataupun kalimat-kalimatnya kepada mahasiswa sesuai dengan jumlah kelompok yang telah diatur.

2) Mufradat atau kalimat-kalimat tersebut ditulis atau diketik dengan jelas dengan mengosongkan ruang ekstra antara setiap mufradat dengan mufradat lain ataupun kalimat dengan kalimat lain.

3) Lembaran kisah tersebut dipotong-potong dengan menggunakan gunting menjadi beberapa bagian, satu mufradat ataupun kalimat berada dalam satu bagian / potongan.

B. Dalam Kelas

1) Dosen membagi mahasiswa dalam beberapa kelompok

2) Potongan kertas yang berisi mufradat ataupun kalimat dibagikan secara acak kepada mahasiswa dalam setiap kelompok.

3) Dosen meminta mahasiswa untuk menghafalkan mufradat ataupun kalimat yang ada dalam potongann tersebut akan tetapi mahasiswa

\footnotetext{
${ }^{14}$ Bandingkan dengan Azhar Arsyad, Bahasa Arab dan Metode Pengajarannya; Beberapa Pokok Pikiran (Cet.III; Yogyakarta: Pustaka Pelajar, 2010), h. 80-28.
} 
tidak diperbolehkan menulis apapun atau memperlihatkannnya kepada mahasiswa yang lainnya.

4) Dosen meminta perwakilan dari mahasiswa untuk mengumpulkan kembali setiap potongan kertas yang telah dibagikan tadi.

5) Setelah semua potongan kertas terkumpul di hadapan dosen, dosen memberi kesempatan kepada semua kelompok untuk berdiskusi tentang mufradat ataupun kalimat yang telah dihafalkan masingmasing dan berperan aktif dalam merangkai cerita yang teratur.

6) Dosen mulai mempersilahkan kelompok demi kelompok untuk merangkaikan mufradat ataupun kalimat yang telah dihafalkan tersebut, sehingga terangkai menjadi suatu topik cerita sesuai yang telah dipersiapkan / ditentukan oleh dosen.

7) Dosen mempersilahkan kelompok demi kelompok untuk tampil mempresentasikan cerita yang telah dirangkai bersama.

8) Setiap mahasiswa dalam kelompok tersebut harus menyebutkan secara nyaring mufradat ataupun kalimat yang telah dihafal.

9) Perwakilan dari kelompok menyampaikan rangkaian topik cerita yang telah mereka susun.

10) Kelompok yang lain mendengarkan dengan seksama daan bila perlu mufradat ataupun kalimat tersebut dicatat oleh setiap mahasiswa

11) Setelah semua kelompok tampil mempresentasikan, Dosen memperlihatkan teks yang lengkap di hadapan kelas secara jelas, sehingga bilamana ada kekeliruan dari hasil presentasi tadi bisa dengan mudah diperbaiki ataupun ditulis ulang dalam catatan setiap mahasiswa.

\section{d. Strategi 4}

1) Dosen memberikan pendahuluan yang berkaitan dengan berbagai hal tentang materi yang disajikan baik berupa appersepsi, atau tes awal tentang materi atau yang lainnya.

2) Dosen memberikan kosakata dan istilah yang dianggap sukar. Ini diberikan dengan defenisi-defenisi dan contoh-cntoh dalam kalimat.

3) Dosen menyajikan teks cerita tertentu. Teks ini dibaca secara diam ( alqira'aah al-shamitah / silent reading ) selama kurang lebih 10-15 menit atau disesuaikan dengan alokasi waktu yang tersedia. Bisa juga dosen menugaskan mahasiswa untuk membaca teks tersebut di rumah sebelum memasuki perkuliahan, hal ini lebih efisien sehingga dosen dapat lebih leluasa mengembangkan teks cerita di kelas.

4) Diskusi mengenai isi teks cerita.

5) Pembicaraan atau penjelasan tentang tata bahasa secara singkat jika diperlukan untuk membantu pemahaman mahasiswa tentang mufradat dan isi teks cerita.

6) Jika di awal pertemuan dosen belum memberikan penjelasan mufradat yang dianggap sukar dan relevan dengan materi perkuliahan, maka pada langkah ini bisa dilakukan.

7) Di akhir pertemuan dosen memberikan tugas kepada mahasiswa tentang isi teks cerita, misalnya membuat pengolompokan mufradat, menghafal mufradat, dan lain sebagainya. 
Berikut ini contoh teks cerita yang bisa digunakan untuk melatih penguasaan mufradat mahasiswa:

$$
\text { حفلة مولد الرسول }
$$

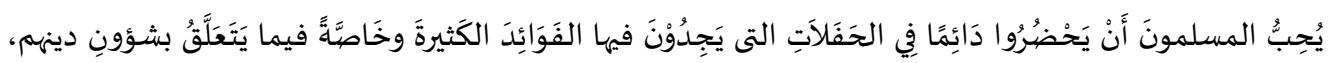

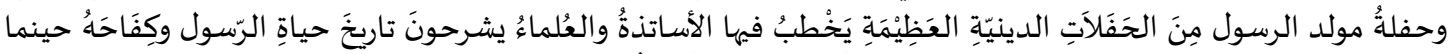

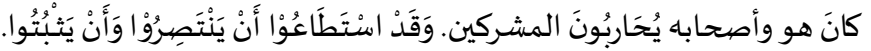

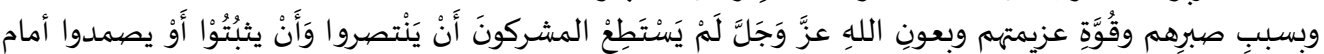

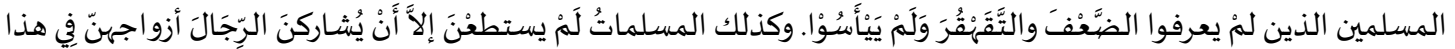

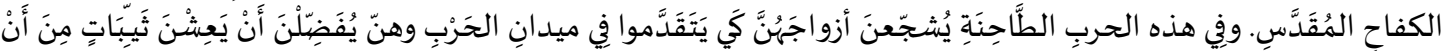

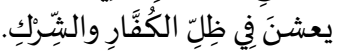

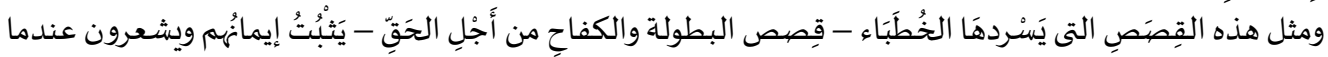

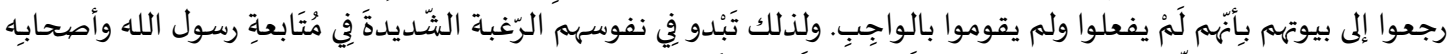

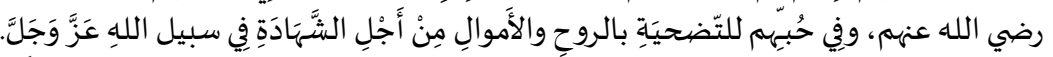

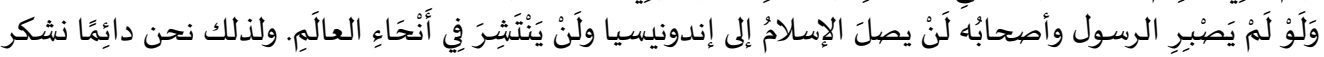

الله على فضله ونعمِِِ العظيمِِة نعمة الإسلام والإيمان.

\section{Kesimpulan}

Proses pembelajaran bahasa Arab dan berbagai metode pembelajarannya menjadi tantangan tersendiri bagi dosen dan mahasiswa. Media teks cerita merupakan salah satu media pembelajaran yang efektif digunakan dalam melatih penguasaan mufradat mahasiswa. Pembelajaran media teks cerita ini dikembangkan melalui beberapa langkah strategis, adapun langkah- langkah penggunaan media berbasis teks cerita untuk meningkatkan penguasaaan mufradat seperti berikut ini : dosen memberikan teks cerita kepada mahasiswa dan mahasiswa menelaah teks tersebut dan kemudian menghimpun mufradat yang masih belum diketahui sehingga mahasiswa akan lebih terarah pada saat dosen menjelaskannya. 


\section{Daftar Pustaka}

Arsyad, Azhar. Bahasa Arab dan Metode Pengajarannya; Beberapa Pokok Pikiran. Cet. III; Yogyakarta: Pustaka Pelajar, 2010.

Arsyad, Azhar. Media Pembelajaran. Cet. V; Jakarta: RajaGrafindo Persada, 2004.

Haniah, "Manajemen Perencanaan Kurikulum Bahasa Arab", Jurnal PELITA, Volume 4, Nomor 2, Juli-Desember 2012. Dalam http://repositori.uinalauddin.ac.id/1973/1/Jurnal\%20Haniah_Pelita_2012.pdf

Hermawan, Acep. Metodologi Pembelajaran Bahasa Arab. Cet. IV; Bandung: PT Remaja Rosdakarya, 2014.

Khalid, H.M. Rusydi. “Al-Bahru al-Muhīt”, Jurnal Adabiyah Vol. 15 Nomor 2/2015. Dalam http://journal.uin-alauddin.ac.id/index.php/adabiyah/article/view/702

Nasution, Harun. Islam Rasional: Gagasan dan Pemikiran. Cet. I; Bandung: Mizan, 1995.

Syafri, Ulil Amri. Pendidikan Karakter Berbasis Al-Qur'an. Cet.II; Jakarta: RajaGrafindo Persada, 2014

Salim, Latifah. "Peranan Bahasa Arab terhadap Ilmu Pengetahuan", Jurnal Adabiyah Vol. 15 Nomor 2/2015. Dalam http://journal.uinalauddin.ac.id/index.php/adabiyah/article/view/701/pdf 50

Yusuf, Tayar dan Syaiful Anwar, Metodologi Pengajaran Agama dan Bahasa Arab. Cet. II; Jakarta: RajaGrafindo Persada, 1997

Zulhannan, Teknik Pembelajaran Bahasa Arab Interaktif. Cet. II; Jakarta; PT RajaGrafindo Persada, 2015. 